\title{
PECULIARIDADES DO CONTRATO DE ARRENDAMENTO PORTUÁRIO
}

\author{
FLoRIANO DE AZEVEDO MARQUES NETO* \\ FÁBIO BARBALHO LEITE* ${ }^{* *}$
}

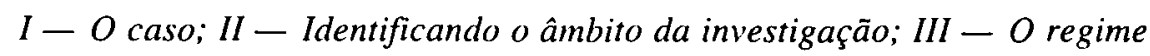
jurídico dos portos e da atividade neles desenvolvida; $I V-O$ contrato de arrendamento; IV.I - A natureza do contrato de arrendamento de instalações portuárias; IV.2 - O regime do contrato de arrendamento de instalações portuárias; IV.2.1 - O porto é bem público; IV.2.2 - O porto é dedicado à finalidade pública específica; $V$ - Implicações do regime juridico de serviço público da atividade desenvolvida pela empresa ao ensejo do novo contrato; VI - Implicações do regime de contrato administrativo para a compreensão da ampliação do objeto imediato do segundo contrato de arrendamento - peculiaridades do contrato en causa; VII - A ampliação do contrato como legítimo ato administrativo ressarcitório da "empresa" contratada e neutralizador de claro e fundado direito indenizatório ganhos para o interesse público, referidos ao serviço público em causa e ao patrimônio público tutelado pela concessionária; VIII - Compatibilidade entre a ampliação contratual cogitada e o princípio da isonomia; IX - Conclusão

I-O caso

Cuida-se aqui de estudo concernente à ampliação de escopo contratual, cogitada em Contrato de Arrendamento de Instalação Portuária.

i) A empresa interessada no presente contrato de arrendamento de instalação portuária com concessionária de Serviços Públicos, cujo objeto consubstancia-se no

* Advogado. Doutor em Direito pela USP. Professor - Doutor do Departamento de Direito. Público e do Estado da Universidade de São Paulo

** Advogado. Mestre em Direito Público pela PUC/SP. Professor no Curso de Pós-Graduação Lato Sensu em Direito do Estado da Faculdade de Direito de Itu/SP

R. Dir. Adm.,

Rio de Janeiro, 231: 269-295,

Jan./Mar. 2003 
“arrendamento para exploração de INSTALAÇÃO PORTUÁRIA, com utilização de área, sob administração da outra parte contratante, considerada como retro-área remota, localizada em porto marítimo, abrangendo armazéns, conforme indicações e delimitações apresentadas na Planta de Localização da Área Arrendada ...".

ii) Sobre dito contrato chama-nos ainda a empresa interessada neste estudo, a atenção ao teor de cláusula contratual que prescreve que "AS INSTALAÇÕES PORTUÁRIAS deverão ser exploradas, operadas, conservadas e melhoradas pela $A R$. RENDATÁRIA, podendo ser modernizadas e ampliadas nos termos do Artigo $4^{\circ}$, parágrafo quarto, inciso VIII. da Lei $n^{\circ} 8.630 / 93^{\prime \prime}$; sendo certo que essa disposição constava originalmente da minuta contratual que acompanhou o Instrumento Convocatório do certame precedente à formalização da avença em comento.

iii) Além desse contrato, a empresa entretém outro similar, conquanto mais antigo, voltado ao arrendamento d'outras instalações portuárias; tal contrato abrange o arrendamento de outras áreas.

iv) O primeiro contrato, entretanto, encontra-se em vias de ter sua execução comprometida em vista da abertura de nova via interna ao próprio Porto, a qual passará justamente em meio à área abrangida por essa avença.

v) Essa avenida, demonstram os desenhos de seu projeto, ainda que não abarque toda a área operada pela empresa com fundamento no contrato inicial, quadra por inviabilizar operacional e economicamente o uso da parcela de área restante, donde a inevitabilidade da rescisão contratual indireta, uma vez implementada a nova via portuária.

Assim, a rescisão contratual a se operar quanto ao primeiro contrato dever-se-á a uma atuação da própria concessionária, que, implementando um projeto viário seu, provoca o exaurimento da viabilidade operacional e econômica da exploração do objeto contratado mediante a segunda avença retrocitada.

Cogitam, todavia, as partes - como procedimento que, otimizando as potencialidades econômicas do novo contrato, sirva também a contornar consequiências responsabilizatórias da rescisão do contrato inicial - de ampliar o objeto contratual imediato do segundo contrato para que abranja o arrendamento de áreas adjacentes ao Armazém.

Sumariada assim a consulta, passamos ao enfrentamento das questões nela enredadas para, ao cabo, podermos, secundados em consistente estofo teórico, respondê-las.

\section{II - Identificando o âmbito da investigação}

Como desde início adiantado, a indagação formulada gira em torno de ampliação do objeto contratual imediato de um contrato de arrendamento de instalações portuárias firmado pela empresa.

Tomássemos tal contrato como um contrato administrativo de regime comum - i.é., integral e exclusivamente submetido às concernentes disposições da Lei $n^{0}$ 8.666/93 - e todo o foco da investigação cingir-se-ia basicamente a analisar eventual observância dos limites de acréscimo de objeto contratual positivados no artigo 65 , 
$\S \S 1^{\circ} \mathrm{e} 2^{\circ}$ da Lei $n^{\circ} 8.666 / 93$. Ainda nessa hipótese, entretanto, certamente o problema não seria reduzido à singeleza de uma operação matemática (saber se o objeto acrescido ultrapassa ou não $25 \%$ do objeto original), porquanto, consoante acuradas doutrina e jurisprudência, os limites em referência podem e devem ser ultrapassados em várias hipóteses legais. Como ilustração, servem hipóteses de:

(i) reequilíbrio econômico-financeiro: onde a impositividade - por direito subjetivo de uma das partes - da restauração da equação econômica original não pode ser limitada por nenhum valor a priori senão pela proporcionalidade do abalo sofrido pela dita equação.

(ii) modificação do projeto ou das especificações contratuais para melhor adequação técnica aos seus objetivos: hipótese em que a impositividade do ótimo atingimento do interesse público instrumentado pela contratação exige a alteração contratual, a qual, aqui também, não poderá estar constrangida por valores ou outros dados a priori (abstratos, genéricos e anteriores ao próprio problema), senão ao que tecnicamente necessário - segundo um juízo administrativo técnico-discricionário pautado pelos princípios da razoabilidade e da proporcionalidade - para fazer com que o contrato atinja o objeto público que o justifica. ${ }^{1}$

Sem embargo, desde já temos que os contratos em causa, sem azo à dúvida contratos administrativos (o que mais adiante melhor justificamos), apresentam algumas peculiaridades de intensidade em seu regime jurídico quando comparado este ao que chamaremos de regime jurídico comum das avenças administrativas. Tais peculiaridades ensejam considerar a limitação das ampliações contratuais, no caso concreto, não em face de valores proporcionais definidos a priori, mas, sim, em face de parâmetros materiais referenciados aos Princípios Jurídicos da Finalidade (Interesse Público), da Razoabilidade e da Proporcionalidade.

Nesse diapasão, o diploma normativo primacial para entender essas peculiaridades do regime jurídico dos contratos de arrendamentos de instalações portuárias, sem desconsiderar a incidência da legislação comum (Lei $n^{\circ} 8.666 / 93$, artigos 54 e seguintes), é a Lei $\mathrm{n}^{\circ} 8.630$, de 25 de fevereiro de 1993, que institui o Regime Jurídico da Exploração dos Portos Organizados e das Instalações Portuárias. A partir dele, mas não somente diante dele, trataremos de delinear o regime jurídico peculiar (ainda que, já adiantamos, de forma alguma absolutamente original) dos contratos em causa. Nessa trilha, o emprego supra operado da expressão objeto contratual imediato noticia um pouco dessa peculiaridade jurídica da contratação em causa,

I Apenas como ilustração de escólio doutrinário, a acuidade de Carlos Ari Sundfeld: "esses limites não são aplicáveis em hipótese de elevação do preço contratual motivada pela necessidade de recompor a equação atingida por sujeições imprevistas, pela álea econônica extraordinária ou pelo fato do príncipe. Nessas situaçōes, o objeto do contrato nāo é alterado, quer em sua natureza. guer em sua extensão; a modificação do preço impōe-se apenas para remunerar o contratado pela execução do exato objeto do contrato. Não haveria por que, em conseqiiência, limitar o acréscimo de valor possivel nessas hipóteses, sabendo-se que os limites previstos no artigo $65, \S 1^{\circ}$ o foram para impedir que, por meio de aditamentos contratuais, a Administração acabasse por costear a exigência de licitação. " (Licitação e Contratos Administrativos, São Paulo, Malheiros, $2^{2}$ edição, 1995. páginas 244 e 245). 
peculiaridade essa que demanda algum esforço (o menor e mais singelo possível) de nomeação de certas realidades que, senão novas em substância, são novas em intensidade (se é que novas de qualquer modo).

Conhecidas as linhas-mestras desse regime, será a vez de, entre elas, identificar as diretrizes principiológicas e regras que poderão nos levar à conclusão e assim construir ${ }^{2}$ a resposta à indagação.

Do que se pode anteolhar, a investigação não é pequena. Como aqui a impressão de que a mesma ainda será realizada constitui nada mais que uma "ilusão de ótica" literária, para que a objetividade e a síntese restem o mais possível prestigiadas por uma peça que, antes de tudo, deve anelar a funcionalidade necessária à praxis jurídica, é oportuno quebrar momentaneamente essa ilusão discursiva, antecipando, a título de pauta da redação, as conclusões do parecer. Assim, a ampliação do objeto contratual imediato do contrato é lícita, pois:

i) A atividade desenvolvida ao ensejo de referido contrato é de serviço público"3, o que submete a relação contratual a um regime juspublicista; neste, entre outros, vige o Princípio da Continuidade do Serviço Público. impondo aos agentes públicos incumbidos da prestação do serviço velar com todos os meios possíveis pela continuidade da prestação do serviço, continuidade esta que não se cinge à mera permanência de uma operação material, mas, sim, a permanência ótima da operação material em que se consubstancia o serviço: sob essa diretriz, a ampliação do objeto contratual imediato da referida avença homenageia a persistência da operação dantes desenvolvida na área abrangida pelo contrato inicial e a otimização da funcionalidade do espaço das instalações portuárias adjacentes à área abrangida inicialmente pelo novo contrato.

ii) O contrato em tela é um contrato administrativo, e, por decorrência do regime geral dos contratos administrativos, caracteriza-se pela alterabilidade como regra imanente; demais, por peculiaridade jurídica defluída da Lei $\mathrm{n}^{\circ} 8.630 / 93$, tal altera-

2 Sim, construir, pois, já vai longe o tempo em que se imaginava que as respostas para os problemas de relevo na praxis jurídica seriam descobertas, encontradas como se estivessem no tex to normativo originalmente prontas antes de qualquer intervenção hermenêutica. Entre nós, ao menos desde Carlos Maximiliano, sabemos que assim não se dá. E, no mundo, pclo menos desde Kelsen e sua norma como moldura de possíveis interpretações, ninguém que tenha ultrapassado os rudimentos do Direito duvida que o aplicador da norma participa da construção da solução jurídica para o problema da praxis desde o instante em que se põe a necessidade de interpretar o ordenamento jurídico. Mas isso é uma digressão que já se alonga.

3 Pouco importa se esta é concedida à concessionária e por ela diretamente prestada ou se parcela dessa atividade concedida a ela é prestada mediante a atuação de particulares legitimados a tanto com base em contratos de arrendamento de instalações portuárias. O serviço público não perde sua natureza jurídica (i.é., seu regime jurídico) mediante atos de delegação (como o são a concessão, a permissão e, in casu consoante adiante melhor se vê, o arrendamento portuário): "A concessão ou a permissão de uma dada atividade não transforma sua natureza de serviço público. Na prestação deste, o critério orientador é sempre a satisfação de uma utilidade pública. quer seja prestador o Estado ou um concessionário ou permissionário particular." (Fábio Barbalho Leite, "O Conceito de Serviço Público para o Direito Tributário", in Direito Tributário Constitucional, Nazzar Carrazza, Elizabeth (Coordenação), São Paulo, Max Limonad, 1999, página 209). 
bilidade é característica intensificada nos contratos de arrendamento de instalações portuárias, ensejando a ampliação do objeto contratual original imediato quando (sob apreciação discricionária do agente administrativo competente) as condições estruturais da área adjacente àquela objeto do segundo contrato podem ser otimizadas e assim potencializada a eficiência do serviço público em causa - estendendo-se a operação do contrato em tela sobre essas áreas adjacentes.

iii) Tal opção administrativa (discricionária) tanto mais se revela legítima quando notada que a mesma neutraliza, por compensação material, claras e fundadas pretensões ressarcitórias da empresa interessada, as quais adviriam em desfavor da outra parte (e assim do patrimônio público que a mesma tutela) com a rescisão do primeiro contrato por fato atribuível à responsabilidade daquela parte.

iv) Demais, não comparece afronta à isonomia no caso em análise.

Para alicerçar tais conclusões, cabem-nos expor: i) o regime jurídico atinente à atividade desenvolvida ao ensejo da execução do novo contrato; ii) a natureza jurídica do contrato de arrendamento de instalações portuárias e sua injunção para o caso concreto; iii) as injunções do Princípio da Isonomia em face do caso concreto (em que, como será visto, não se põe exatamente alteração contratual, mas, sim, ampliação contratual; diferença que, agora, malgrado parecer mais jogo de palavras, será adiante melhor exposta).

\section{III - O regime jurídico dos portos e da atividade neles desenvolvida}

A Constituição de 1988 alterou consideravelmente o tratamento jurídico reservado à atividade portuária em comparação com suas predecessoras. As Cartas Constitucionais de 1946 e de 1967 referiam tão-somente a competência da União de legislar sobre o regime dos portos e da navegação de cabotagem, mas silenciavam sobre a exploração da atividade portuária pelo Estado. Diversamente, a Constituição de 1988, além de reservar à União a competência para legislar sobre a matéria (artigo $22, X)$, estabeleceu em seu artigo 21 , inciso XII, que compete à União:

"XII - explorar, diretamente ou mediante autorização, concessão ou permissão: (...) f) os portos marítimos, fluviais e lacustres;"

Sobranceira doutrina ensina que a CF, artigo 21 estabelece os serviços públicos federais, que devem ser assegurados pela União, diretamente ou por meio de delegação, esta mediante concessão ou permissão. Ao incluir expressamente a exploração dos portos no rol dos serviços públicos de competência da União, a Lei Maior atribuiu ao Estado o poder-dever de explorar tal atividade, exatamente da mesma forma que os serviços de radiodifusão sonora e de sons e imagens, os serviços de telecomunicações, as instalações de energia elétrica, os serviços postais etc.

A exploração dos portos é, assim, serviço público, ainda que existam posições isoladas que afirmam o contrário. ${ }^{4} \mathrm{~A}$ favor da natureza de serviço público para a

4 Ivan Barbosa Rigolin, por exemplo, em parecer inédito datado de 13 de janeiro de 1999, sustenta que a expressão "explorar" constante do texto constitucional indicaria que a atividade portuária 
atividade em pauta, os jurispublicistas das mais diversas vertentes do direito administrativo, entre os quais Celso Antônio Bandeira de $\mathrm{Mello}^{5}$, Carmen Lúcia Antunes Rocha ${ }^{6}$ e Marçal Justen Filho ${ }^{7}$, rol meramente exemplificativo. Deixemos esse ponto pacífico, portanto, de lado.

Oferece maior oportunidade ao debate, entretanto, saber qual é a natureza jurídica dos serviços públicos de "portos marítimos fluviais e lacustres" de que trata a Constituição. Escassa a doutrina a respeito, a pouca existente pode ser dividida em duas correntes.

Uma primeira, defendida por Tércio Sampaio Ferraz Júnior, sustenta que o serviço público de que trata a Constituição restringe-se ao porto, na qualidade de universalidade de bens, não compreendendo os particulares que arrendam parcelas

não se reveste da natureza de serviço público. Segundo o autor, "serviço público a União não explora, presta apenas. Quem explora serviço público é o concessionário particular. mas para ele o serviço público de que é concessionário em verdade se traduz como exploraçāo de atividade econômica, junto ao usuário que lhe paga tarifas. Apenas para o Poder Público que concedeu o que pare ele seria serviço público irá enxergar a prestação pelo concessionário como sendo prestação de serviço público. O particular concessionário não o enxerga assim, porque sendo empresa privada capitalista deseja lucro, oriundo da exploração da atividade econômica que o Poder Público enxerga como serviço público. Não tendo lucro o particular não será concessionário desinteressando-se da atividade econômica que para ele é a digamos assim para clareza, exploração do seniç̧o público. Repita-se: serviço público a Uniāo não explora, mas presta à população. Se explora, é porque não se trata de serviço público.". Sem embargo do respeito que dedicamos ao autor, a nosso ver - e nisso estamos acompanhados de toda a doutrina administrativa autorizada - a afirmação não procede. Basta recordar que os serviços públicos são espécie do gênero atividade econômica $\mathrm{cm}$ sentido amplo, integrando-o ao mesmo título que as atividades econômicas em sentido estrito a que se refere o autor. Nesse sentido, a sistemática constitucional é coerente e reproduz a definição mencionada, utilizando o termo "explorar" de maneira indistinta para as atividades econômicas (stricto sensu) e para os serviços públicos.

5 Segundo o autor, "A Carta Magna do País já indica, expressamente, alguns serviços antecipadamente propostos como da alçada do Poder Público federal. Serão, pois, obrigatoriamente serviços públicos (obviamente quando volvidos à satisfaçāo da coletividade em geral) os arrolados como de competência das entidades públicas." (Curso de Direito Administrativo, $14^{\mathrm{a}}$ edição, São Paulo. Malheiros, 2002, página 612).

6 "Alguns dos dispositivos constitucionais deixam clara a definição de algumas atividades como serviços públicos, superando-se o debate quanto à sua qualificação e quase que inteiramente quanto ao regime de Direito que sobre eles deve incidir no Direito Positivo fundamental." (Estudo sobre Concessāo e Permissão de Serviço Público no Direito Brasileiro, São Paulo, Saraiva, 1996, página 20).

7 "Existem serviços püblicos por inerência, assim entendidos aqueles cuja caracterizaçāo deriva (explícita ou implicitamente) da Constituição. Ao discriminar competências dos diversos entes federados ou ao estabelecer atribuiçóes do Estado, a Carta qualifica certos serviços como públicos. $O$ artigo 21, por exemplo, contém diversas previsões acerca de serviços públicos (incisos $X, X I$ e XII). Quanto aos serviços públicos por inerência, não há margem de opção para a legislação infraconstitucional. Sua estruturação far-se-á segundo regime de direito público. pois tal foi imposto pelo legislador constitucional. "(Concessōes de Serviços Públicos, São Paulo, Dialética, 1997). 
territoriais dessa unidade e que ali exercem atividade privada desvinculada do serviço público do porto organizado. Segundo o autor:

"Concedido é o porto (artigo 21, XII, $f$ da $C F$ ), enquanto uma unidade organizada. Diferente da concessão (e da delegação) do porto, isto é, da sua exploração como um todo é a exploração de instalação portuária de uso público ou privativo, que é exploração de parte do objeto da concessão (e da delegação) e que pressupõe a prévia concessão (ou delegação). Havendo já a concessão (ou delegação) do todo organizado, a relação de exploração de parte deste todo não se faz mais por concessão (ou delegação) que, por pressuposto, já abrangeu a totalidade. (...) Entende-se neste sentido que a Lei ${ }^{\circ}$ 8.630, de 25.02.93, que dispõe sobre o regime jurídico da exploração dos portos organizados e das instalações portuárias, tenha distinguido entre a exploração do porto organizado, pela União, diretamente ou mediante concessão (artigo $1^{\circ}$ ), do arrendamento de instalações portuárias quando dentro dos limites do porto organizado (artigo $4^{\circ}, I$ ). ${ }^{\prime 8}$

A tese aí assenta-se, portanto, em duas constatações. Uma, que releva do direito positivo: a de que a Lei $n^{\circ} 8.630 / 93$ (Lei dos Portos) distingue, efetivamente, entre a concessão do porto organizado (artigo $1^{\circ}$ ) e os arrendamentos (artigo $4^{\circ}, \mathrm{I}$ ). Seriam concessionárias as Companhias de Docas estabelecidas nos Estados brasileiros, como a CODESP, a CODEBA e tantas outras, não os arrendatários de armazéns ou instalações portuárias. Outra, que parte de uma constatação empírica: esses particulares, ao contrário das Companhias de Docas acima mencionadas, exercem atividade intrinsecamente distinta dessas companhias, de caráter eminentemente privatista.

A segunda corrente sustenta, em sentido contrário, que os particulares arrendatários de parcela dos bens que integram o porto desempenham, ali, funções que tocam ao núcleo do serviço público assentado constitucionalmente. Assim em, por exemplo, Caio Tácito, ao lecionar que "In]os portos organizados nasce e se mantém uma relação publicística, imbricada na concessão de serviço público, que tem como origem a legislação monárquica de 1869 e se prolonga até o Estatuto de 1993."9

Nessa linha, mais do que a outorga para o uso de bem integrante do porto, os arrendatários assumem obrigações e direitos típicos de concessionários de serviço público, que não se relacionam propriamente ao uso do bem, mas sim à atividade ali desempenhada. Por isso é que o regime do arrendamento constante da Lei dos Portos abrange regras típicas da concessão de serviços públicos, sejam elas relativas aos padrões de qualidade e de metas do serviço (artigo $4^{\circ}$, $\S 4^{\circ}$, II e III), aos direitos e deveres dos usuários (artigo $4^{\circ}, \S 4^{\circ}, \mathrm{VI}$ ), à responsabilidade do arrendatário pela inexecução ou deficiente execução dos serviços (artigo $4^{\circ}, \S 4^{\circ}, \mathrm{XII}$ ) e à reversibilidade dos bens (artigo $4^{\circ}, \S 4^{\circ}$, VII). Acrescemos a Lei ainda dispor que a reversão dos investimentos realizados pelo particular obedecerá ao "disposto na lei

8 "Porto - Arrendamento - Cessão e Prorrogação do Contrato", in Revista Trimestral de Direito Público, São Paulo, Malheiros, abril a junho de 1999, n²6, página 146.

9 Tácito, Caio, "Regime de Portos. Terminal Privativo. Permissāo", in Temas de Direito Público (Estudos e Pareceres), Rio de Janeiro, Editora Renovar, 1997, volume 2, página 1.246. 
que regulainenta o regime de concessão e permissão de serviços públicos" (artigo $\left.4^{\circ}, \S 6^{\circ}\right) .{ }^{10}$

Do esforço exegético do texto constitucional surge conclusão incontornável. O diploma não outorgou à União o dever de "organizar" os portos marítimos, fluviais e lacustres, "administrá-los" ou "viabilizar" a sua exploração. Atribui-lhe, isso sim, o poder-dever de explorá-los. Cabe à União Federal, portanto, realizar a tarefa em causa e todos aqueles que participarem dessa atividade - a de embarque e desembarque de pessoas e mercadorias, e todas as atividades que the são correlatas ou acessórias - executarão parcela do serviço público atribuído àquele ente federativo. Nessa senda, o desempenho de atividades atreladas à exploração do porto para os fins que se destina estará imbricado no serviço público outorgado à União.

No entanto, o texto constitucional admite - como é o caso no setor das telecomunicações - que a delegação da exploração do porto a particulares se dè por meio de concessão, permissão ou autorização. Nesse sentido, a Constituição deve ser interpretada sistematicamente, com o sopesamento dos demais preceitos nela contidos. Ora, segundo o artigo 175 da Carta Maior, os serviços públicos serão prestados diretamente ou por meio de concessão e permissão, sempre precedidas de licitação. Assim, ao admitir que a exploração dos portos se dê também mediante autorização, o legislador constituinte implicitamente estabeleceu que parte dos serviços compreendidos na atividade portuária fosse prestada além do quadro estreito do regime de direito público incidente sobre os serviços públicos stricto sensu, como ocorre com o setor das telecomunicações. "

Cumpre determinar, nesse sentido, quais os serviços que serão objeto de autorização - e que, portanto, sujeitam-se a regime regulatório mais lasso (privado) -. e quais os serviços que, integrando o núcleo do serviço público estabelecido no artigo 21 da Constituição, serão objeto de permissão e concessão. Nesse passo, o complexo regime a que os contratos de arrendamento são submetidos é o exato reflexo da dificuldade de determinar qual a parcela de serviços prestados por particulares que se encontra sob o manto do serviço público estabelecido pela Constituição Federal. É o que adiante se verá.

\section{$I V-O$ contrato de arrendamento}

Não é novidade o uso do instituto do arrendamento como instrumento de regulação da atuação do particular no Porto. Entretanto, a Lei dos Portos alterou significativamente as feições e o âmbito da delegação que se perfaz por meio do

10 A esse respeito, ver o interessante parecer de Alice Gonzales Borgcs, "Instalações Portuárias

- Contrato de Arrendamento", in Revista de Direito Administrativo, Rio de Janciro, Editora Renovar, outubro a dezembro de 1997, volume 210, página 337.

11 Sobre o assunto, Floriano de Azevedo Marques Neto, "Direito das Telecomunicaçōes e ANA$T E L "$, in Direito Administrativo Econômico, Sundfeld, Carlos Ary (coordenação), páginas 300 e seguintes. 
arrendamento. Tal alteração tem efeitos não somente sobre (i) a natureza do contrato de arrendamento, como também (ii) sobre o regime que lhe é aplicável. Abordemos, portanto, os dois tópicos de maneira segmentada.

\section{IV.I - A natureza do contrato de arrendamento de instalações portuárias}

A doutrina se divide quanto à natureza do contrato de arrendamento no bojo da Lei $n^{\circ} 8.630 / 93$. Além daqueles que sustentam tratar-se de concessão de serviço público, outros afirmam que o arrendamento consiste em concessão de bem público ou de obra pública, e ainda há quem propugne que se trata do arrendamento clássico do direito civil (artigo 679 do Código Civil) aplicado à Administração Pública sob o regime do Decreto-lei $n^{\circ} 9.760 / 46$.

A corrente privatista afirma que a figura do contrato de arrendamento é expressamente prevista na legislação para a contratação pela Administração Pública e integra os chamados contratos privados que podem ser firmados pela administração sobre os bens de sua propriedade, subordinando-se a regime de direito privado tal qual a enfiteuse ou a locação.

Sustentam esses autores, entre os quais o já mencionado Tércio Sampaio Ferraz Júnior, que a exploração de instalações portuárias por agentes econômicos privados é negócio jurídico entre esses e o concessionário. logo, trata-se aqui de um contrato civil da Administração, regido pelo direito privado. Ademais, a marca característica da gestão privada em tal contrato decorre da análise dos direitos que são transferidos em tal operação. Para o autor, ocorre apenas a transferência do uso e do gozo da coisa, recebendo o arrendatário apenas um consentimento para ocupar e explorar a coisa pública, diferentemente do concessionário, que atua como se fosse Estado, pois este, quando do contrato de concessão, recebeu poderes públicos para tal. ${ }^{12} \mathrm{E}$ arremata:

"O uso do instituto do arrendamento para a exploração de atividades portuárias, destarte, é perfeitamente legítimo, ainda que se reconhecesse a existência de bens patrimoniais públicos indisponiveis, bens da entidade pública destinados ao serviço público, que são 'extra conmercium', mas apenas inalienáveis, sendo passíveis, assim, de se objeto de todos os direitos reais que não sejam incompatíveis com seu destino (Diez, Domínio Público, Buenos Aires, 1940, página 113, citando Alessio)." 13

Já a caracterização do arrendamento como uma concessão de serviço público considera. em primeiro lugar, que o simples fato do contrato ter o nome de arrendamento não o faz submeter-se, automaticamente, ao regime do arrendamento previsto no Código Civil e autorizado por meio do Decreto-lei $n^{\circ} 9.760 / 46$. Em Direito não há palavras mágicas, cujo mero uso teria o condão de dar a natureza dos seres jurídicos. Importa, pois, não o nome que se dê ao negócio jurídico, mas sim a natureza das relações jurídicas estabelecidas e as conseqüências que delas advêm.

12 Ferraz Júnior, Tércio Sampaio, op. cit., páginas 146 e seguintes.

13 Ferraz Júnior, Tércio Sampaio, op. cit., página 147. 
Quanto ao arrendamento portuário, trata-se da execução de atividade que integra a exploração do porto, em sentido lato, incidindo portanto na prescrição constitucional do artigo 21, XII, $f$. Ao arrendar terminais ou instalações portuárias, ao arrendatário é facultado tornar-se operador portuário e executar funções típicas desses operadores, inclusive para terceiros, desde que não prejudiquem a prestação dos serviços regulares. ${ }^{14}$ Ainda, como anteriormente demonstrado, as cláusulas essenciais do contrato de arrendamento, constantes do artigo $4^{\circ}$ da Lei dos Portos, possuem disposições típicas da concessão de serviços públicos, como é o caso da reversão dos bens e das metas de qualidade e padrões de serviço.

Daí a posição de que se trata, em realidade, de concessão de serviço público, sustentada por vários autores, dentre os quais Caio Tácito (op. cit.) e Carlos Augusto da Silveira Lobo:

"Os terminais de uso público são subconcessionários de serviços públicos portuários. Os terminais de uso público prestam serviços públicos tal como acima definidos, ou seja: a) o seu objetivo primordial é suplementar os portos organizados na satisfação das necessidades da coletividade, quanto a serviços portuários; $b$ ) qualquer interessado tem o direito de utilizar-se do serviço, em igualdade de condições com os demais usuários; c) o titular de terminal de uso público tem a obrigação de colocar o serviço à disposição dos interessados de forma regular e contínua, sem discriminar entre os usuários; d) seus serviços devem ser remunerados mediante uma tarifa estabelecida pelo poder público, de aplicaçāo geral; e) seus serviços estão sujeitos à fiscalização pelo poder concedente. (...) Em nosso modo de ver, os terminais de uso público se enquadram na figura da subconcessão, prevista no artigo 26 da Lei $n^{\circ}$ 8.987/95 (Lei de Concessões de Serviços Públicos)." 15

Além disso, é de se consignar que, historicamente, os portos sempre foram explorados por regime de concessões, o que deixa claro que as relações estabelecidas com os particulares, no que concerne à exploração do porto, sempre foram ditadas por um viés nitidamente publicista. ${ }^{16}$

Originalmente, a participação dos particulares dava-se claramente por uma concessão de obra pública, aos poucos foi-se acentuando a importância dos serviços prestados pelo particular. A atividade por ele desempenhada tomou maior importância com o aumento da complexização do serviço e da legislação portuária e, nota-

14 Ver, nesse sentido, a clíusula 6.2. do Edital de Concorrência Pública CODESP $n^{\circ}$ 24/97, que originou o contrato de arrendamento objeto da consulta. Apesar de tratar-se de arrendamento de mero armazém (e não de terminal de containers, por exemplo), é previsto no edital que " $a$ ARRENDATÁRIA, desde que não haja prejuizo para a prestação dos serviços, poderá realizar a prestação do serviço de carga, descarga, armazenagem e serviços complementares a terceiros interessados, por sua conta e risco. obedecido o objeto do Contrato."

15 "Os Terminais Portuários Privativos na Lei ${ }^{\circ} 8.630 / 93$ ", in Revista de Direito Administrativo, Rio de Janeiro, Renovar, abril a junho de 2000, n²20, páginas 28 e 29.

16 A esse respeito, sāo importantes as liçōes históricas colacionadas por Caio Tácito e por José Mattos de Vasconcellos, às quais o parágrafo abaixo deve muito, aos quais, para abreviar digressões, remetemos: Vasconcellos, José Mattos de, Direito Administrativo, volume 1, 1937, páginas 29 e seguintes; Tácito, Caio, op. cit., páginas 1243 e seguintes. 
damente, com a Lei $n^{\circ}$ 8.630/93. Assim é que a legislação atualmente vigente não somente obriga (i) a investimentos mínimos na construção das instalações portuárias que lhe incumbem, mas também (ii) a uma movimentação mínima contratual (MMC), bem como (iii) ao atingimento de metas de qualidade na execução de sua atividade e de padrões de atendimento aos seus usuários.

A bom tempo, Alice Gonzales Borges sustenta que, com o advento da nova Lei dos Portos, o arrendamento torna-se mais complexo e conjuga aspectos da concessão de uso de bem público e da concessão de serviço público:

"A Lei $n^{\circ} 8.630 / 93$ institui um 'novo' arrendamento assumindo este uma nova forma contratual, atípica, hibrida e mista, diferenciando-o do arrendamento até então praticado conforme a legislação anterior."

"Dentro da estrutura deste 'novo' arrendamento encontramos as naturezas jurídicas de concessão remunerada de uso de bem público imóvel; de concessão do serviço público, quanto às operações portuárias; e concessão de obra pública (concessão de serviço precedida da construção de obra pública, conforme denominação utilizada na Lei $\left.\mathrm{n}^{\circ} 8.987 / 95\right) . " 17$

$\mathrm{O}$ arrendamento, portanto, caminha-se a caracterizar, a partir do novo regime estabelecido pela Lei dos Portos, uma subconcessão sui generis de serviço público, guardando traços da concessão de uso de bem público que está em sua origem. Nisso, vai a consideração das pesadas exigências relativas ao desempenho de serviço com quantidades, padrões e metas mínimos. Fosse o arrendamento uma mera concessão de uso de bem público ou ainda um contrato regido estritamente pelo direito civil, a exploração dos serviços pelo particular e a percepção dos frutos decorrentes desse serviço não seriam obrigação, mas sim mera faculdade oferecida ao arrendatário. Caberia a ele escolher como melhor aproveitar-se da exploração do bem que lhe fora concedido. $^{18}$

17 "Instalações Portuárias - Contrato de Arrendamento", in Revista de Direito Administrativo, Rio de Janeiro, Editora Renovar, outubro a dezembro de 1997, volume 210, página 337.

18 Vale registrar, derradeiramente, que parte relevante da doutrina enxerga o arrendamento de instalações portuárias como uma concessão de uso de bem público. Nesse sentido, Hely Lopes Meirelles sustenta a impossibilidade da locação ou arrendamento no caso de bens públicos, pois considera inadmissível que a Administração renuncie às prerrogativas jurídicas que the são inerentes, transferindo o uso e o gozo do bem ao particular tal como se faz no regime privado de contratação. Afirma o autor: "A locação é contrato típico do Direito Privado, onde as partes devem manter equivalência de situações nos direitos e obrigações que reciprocamente assumirem. Por isso se conceitua a locação como um contrato bilateral perfeito, oneroso, comutativo e consensual. Ora, no Direito Administrativo jamais se poderá transpassar o uso e gozo do bem público com as características da locação civil, porque implicaria rentincia de poderes irrenunciáveis da Administração. para que ela viesse a se colocar em igualdade com o particular, como é da essência desse contrato no campo do Direito Privado. O só fato de uma lei administrativa, primando pela falta de técnica, referir-se erroneamente a um instituto civil nāo é o bastante para implantá-lo em nosso Direito Público. (...) O que a lei federal denominou impropriamente de "locação" nada mais é que concessão remunerada de uso dos bens do domínio público patrimonial, instituto, esse, perfeitamente conhecido e praticado pela Administração Pública dos povos cultos e regido por normas próprias do Direito Administrativo" (Direito Administrativo Brasilciro, $27^{\star}$ edição, São Paulo, Malheiros Editores, 2002). 
Pode-se sustentar, em sentido contrário, que a preocupação com o uso eficiente do bem público e com a otimização da utilização desse bem escasso (o espaço geográfico no qual se situa o porto), poderia justificar as exigências de quantidades mínimas e de qualidade do serviço, sem desnaturar a essência original do contrato, que era a de concessão de obra pública. No entanto, a nosso ver, a ordem de preceitos e de exigências en relação aos serviços desempenhados pelo particular, constantes da Lei e dos contratos de arrendamento, vai muito além do mero zelo pelo uso eficiente do bem.

O que se verifica é uma efetiva preocupação e regulação, pelo contrato, da atividade a ser exercida pelo particular. Assim é que, como assinalado anteriormente, não apenas (i) são fixadas quantidades mínimas de movimentação de cargas na área arrendada, como também (ii) os direitos dos usuários dos serviços prestados pelos arrendatários, além (iii) das cláusulas de reversão dos bens e de metas a serem atingidas em relação aos serviços. Longe de ser simples escolha do particular, o exercício da atividade portuária é uma exigência contratual imposta pelo Poder Concedente, sendo, assim. impossível cingir o âmbito do arrendamento à mera concessão de uso ou ao arrendamento ditado pelo Código Civil (que se assemelha à locação).

De qualquer forma, sublinhamos que o amálgama de caracteres acima apontados (concessão de serviço com traços ainda de concessão de uso de bem público) bem indica não restar o assunto aqui exaurido. As respostas ora encontradas, sem porem termo à investigação teórica, valem mais como constatações suficientes para responder o problema trazido pela indagação. E é exclusivamente nesse fito que aqui nos empenhamos.

Insta, agora, falar do regime aplicável ao arrendamento, que será objeto do tópico seguinte.

\section{IV.2 - O regime do contrato de arrendamento de instalações portuárias}

A falta de consenso quanto à natureza efetiva do contrato de arrendamento reflete-se, evidentemente, em controvérsia quanto ao regime aplicável ao contrato de arrendamento. A divergência dá-se entre os que defendem a colocação desse contrato sob a égide do Direito Privado, ainda que com cláusulas típicas de direito público e prévia licitação, e aqueles que não vislumbram, no acordo, submissão senão ao direito público.

Não pode, todavia, haver dúvidas quanto ao caráter publicista dos contratos de arrendamento, seja i) pelo fato de o território do porto em que se insere o contrato de arrendamento ser bem público; seja ii) porque tal bem é afeto à finalidade específica de serviço público, fazendo incidir sobre a atividade uma regulação específica. Vejamos cada una dessas afirmações.

\section{IV.2.1 - O porto é bem público}

Não parece haver dúvida de que o contrato de arrendamento incide sobre a parcela dos portos organizados que constitui, obrigatoriamente, bem de natureza 
pública. As áreas conformadoras do Porto Organizado, objeto do contrato de arrendamento, são de domínio público, pois que estarão sempre situadas ou sobre o mar territorial ${ }^{19}$ ou sobre os terrenos de marinha, bens que a própria Constituição Federal reputa como públicos (artigo 20, VI e VII da CF).

Nesse sentido é a lição de Cretella Jr.:

"Nessas condições, a natureza jurídica do lugar abrigado das correntes $e$ ventos, escolhido pelo homem, funcionalmente, para fins de comunicabilidade humana, acompanha a natureza das águas em que se localiza o porto.

Ora, tais águas são bens integrantes do domínio público e, assim, o porto é bem público, quer se ache situado em águas correntes, quer se encontre localizado em águas dormentes." 20

Além disso, como públicos também as disposições da Lei $n^{\circ} 8.630 / 93$ tratam os terrenos dos portos. A legislação admite implicitamente, em seu artigo $4^{\circ}$, inciso II, que os particulares detenham titularidade do domínio útil de áreas situadas dentro do Porto Organizado, mas nunca o domínio direto sobre tais bens. Mesmo nessa hipótese estamos diante, portanto, de bem de propriedade pública.

Mais do que isso, o porto é bem público afeto a uma finalidade específica - a exploração dos serviços públicos de portos marítimos, fluviais e lacustres. São, portanto, bens públicos de uso especial. ${ }^{21}$

Diante da afetação específica do bem para a finalidade publicística, não seria aceitável que o Poder Público abrisse mão de suas prerrogativas institucionais e contratasse a cessão de tais bens a particulares sob o manto do direito privado, conforme a lição já anteriormente perorada de Hely Lopes Meirelles. Também nesse sentido, Maria Sylvia Zanella Di Pietro recorda que o "emprego de institutos do direito privado para transferência de uso privativo somente é possivel no caso de

19 Sobre o assunto, eis a posição de Benjamin Villegas Basavilbaso: "El Código Civil, em su artículo 2340, inciso $2^{\circ}$, estabelece: "Son bienes públicos del Estado general o de los Estados particulares..., los purtes y ancladeros." Este texto, como lo anota Segovia, tiene su fuente em el Esboço de Freitas. Si se observa que tanto los puerios como los ancladeros están necessariamente situados em el mar territorial. $\mathrm{cm}$ los rios o em los lagos, que constituyen bienes del dominio público (supra, 488, 498, 516 y 517), la disposición citada es superflua. Los puertos son siempre dependencias del dominio público por cuanto forman parte de las aguas públicas, correntes o durmientes, donde se hallan situlados." (Derecho Administrativo, volume IV, Argentina, Buenos Aires, 1952, página 637).

20 Tratado do Domínio Píblico, Rio de Janeiro, Editora Forense, 1984, páginas 225 e 226, apud Borges, Alice Gonzales, "Instalą̧ões Portuárias - Contrato de Arrendanıento", in Revista de Direito Administrativo, Rio de Janeiro, Editora Renovar, outubro a dezembro de 1997, volume 210, página 339.

21 Sobre a afetação de bens para uma finalidade pública, Maria Sylvia Zanella Di Pietro anota que "Quando se fala que o bem de uso especial está afetado à realização de um serviço público, como o faz o artigo 66, II, do Código Civil, tem-se que entender a expressão "serviço público" em sentido amplo para abranger toda atividade de interesse geral exercida sob a autoridade ou sob fiscalização do poder público; nem sempre se destina ao uso direto da Administração, podendo ter por objeto o uso por particular, como ocorre com o mercado municipal, o cemitério, o aeroporto, a terra dos silvicolas etc." (Direito Administrativo, $12^{2}$ edição, Atlas, São Paulo, 2000, página 522). 
bens dominicais, já que estes estão dentro do comércio jurídico de direito privado." 22 A contrario sensu, os bens afetos à finalidade pública específica - e mormente os afetos a serviços públicos - não poderão jamais ser objeto das contratações regidas pelo direito privado, entre as quais o arrendamento civil.

\section{IV.2.2 - O porto é dedicado à finalidade pública específica}

Ao tornar a exploração dos portos um serviço público, a Lei Maior faz incidir sobre a atividade uma regulação específica, um regime protetivo especial que o distingue das demais atividades que não receberam tal tratamento constitucional..$^{23}$

Não é por acaso que a alínea $f$ do inciso XII do artigo 21 da Constituição Federal erige à categoria de serviço público a exploração dos portos marítimos, fluviais e lacustres. Trata-se de atividade imprescindível ao desenvolvimento econômico nacional, com evidente interesse público envolvido.

A relevância e essencialidade da atividade alçada ao status de serviço público justificam, no tratamento do direito constitucional, a existência de regulação intensa e alheia à regra de liberdade inerente às relações econômicas (balizadas pelo direito privado, onde a liberdade é a regra). A regulação estatal no âmbito dos serviços públicos, portanto, se efetiva pela aplicação do próprio regime de direito público. Os bens que integram o porto, por serem instrumento pelo qual o Estado cumpre a obrigação que lhe é imposta constitucionalmente de explorar os portos, não poderiam estar alheios a esse regime.

Ainda que se sustentasse, como vimos parte da doutrina fazer, o âmbito do serviço público esgota-se na administração do porto organizado como um todo, não abarcando a cessão dos bens que the integram, ainda assim seria forçoso reconhecer que incide evidente interesse público nos bens que integram o Porto Organizado, por serem, exatamente, o instrumento necessário à consecução dos fins estabelecidos constitucionalmente. Daí que necessariamente serão regidas pelas regras de direito público, e nunca privado, as relaçōes envolvendo os bens do Estado, quando esses forem afetos à finalidade pública, como são os imóveis da zona portuária.

Afirmar o contrário não somente iria contra os princípios mais basilares do direito público, como também geraria paradoxo interno no próprio regime de uso dos bens públicos que integram o porto, sob a sistemática da Lei ${ }^{\circ} 8.630 / 93$. Com

22 Direito Administrativo, $14^{\text {a }}$ edição, São Paulo, Atlas, 2002, página 569.

23 Sobre os efeitos decorrentes da elevação de determinada atividade econômica (em sentido amplo) à categoria de serviço público, note-se que dela decorrem três consequências: i) o Estado assume a obrigação de oferecer a atividade considerada serviço público de forma permanente (continuidade) e a toda gente (accssibilidade, generalidade e universalização); ii) estabelece-se uma restrição à possibilidade de acesso dos particulares à exploração da atividade, pois que ela será prestada por ente estatal ou delegada a particulares por ato específico de outorga; iii) a exploração da atividade, considerada então serviço público, só poderá se dar em regime derrogatório das relações privadas (regime de direito público) Ver, nesse sentido, Floriano de Azevedo Marques Neto "Reestruturação do Setor Postal Brasileiro", in RTDP n 19, 1997, páginas 149 e seguintes. 
efeito, para a cessão dos terminais privativos aplica-se o instituto da permissão de uso de bem público, modalidade de cessão regulada inteiramente pelo direito público. Não seria admissível que a cessão do uso de parcela do porto organizado, dado o maior interesse público que nele se envolve, fosse submetida a regime civilista.

Por todo o exposto, é de se concluir que o regime aplicável aos contratos de arrendamento previstos na Lei $n^{\circ} 8.630 / 93$ será, necessariamente o regime de direito público, seja pelo fato de que a exploração dos portos constitui serviço público, seja porque as instalações portuárias têm natureza de bens públicos de uso especial, seja ainda porque existe evidente interesse público envolvido. Ainda que persista a controvérsia quanto à verdadeira natureza do contrato - concessão de serviço público ou concessão de uso de bem público - não poderá haver dúvida quanto ao regime que lhe é aplicável: trata-se, indiscutivelmente, de regime de direito público. $E$ as contratações em causa, por uma ou outra opção (concessão de serviço ou de uso de bem), sempre serão contratos administrativos.

De rigor: tendo como objeto um bem público e voltado - desde o ângulo do Estado - à satisfação de um interesse público instrumentado pela prestação de um serviço público, o contrato de arrendamento de instalações portuárias tem incontendivelmente natureza jurídica de contrato administrativo. ${ }^{24}$

Impende, agora, indicar os pontos mais relevantes do regime jurídico dos contratos administrativos, que incidem no contrato em comento, e acrescer o que de peculiar antes aventamos sobre o regime da atividade desenvolvida pela empresa interessada ao ensejo de referido contrato. Pela ordem inversa.

\section{$V$ - Implicações do regime jurídico de serviço público da atividade desenvolvida pela empresa ao ensejo do novo contrato}

Não é o caso aqui de se proceder à exposição exaustiva do conteúdo do regime jurídico do serviço público. Ao contrário das matérias tratadas anteriormente, ainda pouco pisadas por nossa doutrina e tribunais, justamente pelo contrário, o tema deste tópico não justifica extensão de monta. Importa-nos identificar que princípio ou regra, dentre aqueles do regime jurídico de serviço público, mais de perto impõe injunções à solução do caso concreto.

24 Aliás, já teria tál contrato natureza administrativa, i.é., já estaria submetido a uma regência extravasante do regime contratual comum, dado ter sido precedido de procedimento licitatório. Nesse sentido, Carlos Ari Sundfeld, com invulgar acuidade, notou-o bem no que atina com as consequiências do regime licitatório sobre o regime jurídico do contrato produzido ao ensejo do certame:"... a licitação nāo é mera condição do contrato. pois interfere intensantente no próprio regime de sua execução. Nos contratos entre particulares, é ampla a possibilidade de alteração. desde que por consenso. Mas, nos da Administração (inclusive naqueles que a doutrina teima em considerar como 'privados'), a mutação é inadmitida se importar em fraude à licitação. Destarte. os limites qualitativos e quantitativos à modificação, impostos pela lei como freio à fraude (artigo $65 . \$ \$ I^{\circ}$ e $2^{\circ}$ ), se aplicam a quaisquer contratos estatais." (Licitação e Contrato Administrativo, São Paulo, Malheiros, $2^{2}$ edição, 1995, página 201). 
Temos que tal é o Princípio da Continuidade do Serviço Público, o qual. corolário "da obrigatoriedade do desempenho de atividade pública", sujeita a $\mathrm{Ad}$ ministração "ao dever de continuidade no desempenho de sua ação" 25 . Essa continuidade do serviço público - no caso, a prestação dos serviços realizados ao ensejo da exploração das instalações portuárias arrendadas pelos dois contratos - obviamente não tem aqui um significado meramente temporal. Continuidade do serviço público não é, no exato sentido jurídico do princípio em causa, apenas permanência no tempo, mas. sim, uma permanência de uma atuação ótima por parte da Administração Pública.

Logo, o Princípio da Continuidade do Serviço Público não prescreve apenas a preservação de uma dada prestação direta ou indireta do Estado. Por ele, Princípio da Continuidade do Serviço Público - compreendido em seu necessário intercurso com os Princípios da Finalidade e da Eficiência Administrativa, CF, artigo 37 -, a continuidade não é alheia de qualquer caractere substancial, mas, sim, prescreve-se como continuidade da prestação pública positivamente qualificada, cada vez melhor, mais eficiente, otimizada quanto ao atingimento da plenitude de seus fins, entre os quais, a produtividade. Conecta-se ainda o Princípio da Continuidade do Serviço Público com aquel'outro da Economicidade, $\mathrm{CF}$, artigo 70, no que aponta a imposição da permanência de uma atuação administrativa eficiente e otimizante de suas potencialidades com o atingimento dos melhores resultados a partir dos menores custos possíveis.

Nesse contexto principiológico, é claro que se veste de color jurídico negativo a abrupta rescisão do primeiro contrato sem que nada se faça para preservar a continuidade do escopo (público) desenvolvido ao seu ensejo. Tal eventualidade tanto mais é reprovável quando, como in casu, passível de ser contornada, dado existirem instalações portuárias ociosas que poderiam prestar-se como compensação, pela rescisão ocorrida no primeiro contrato, à empresa interessada. Mais importante, a compensação aventada volta-se em favor da outra parte contratante e do interesse público implementado pelos serviços prestados ao ensejo da execução do contrato inicial, evitando-se, assim, a perda de continuidade em parcela das atividades portuárias e, mais ainda, otimizando-se prontamente essa mesma continuidade ao se ampliar o uso das instalações portuárias, mediante extensão do objeto imediato do segundo contrato.

A solução cogitada na indagação, homenageia, portanto, vários e caros princípios para a atuação administrativa: o da Continuidade do Serviço Público, o da Eficiência e o da Economicidade. E todos os três, nada obstante com distintas ênfases e ângulos, apontam para a impositividade de se dar plena otimização para as áreas portuárias, mormente as lindeiras àquela originalmente constituinte do objeto imediato do primeiro contrato. Uma tal medida rende à segunda contratação (i) continuidade (ao preservar a prestação da atividade antes desenvolvida no contrato anterior), (ii) eficiência (à medida em que otimiza a operação portuária, evitando-se

25 Celso Antônio Bandeira de Mello, Curso de Direito Administrativo. São Paulo, Malheiros, 13* edição, 2001, página 41. 
perdas) e (iii) economicidade (uma vez que a otimização do uso dos equipamentos públicos dar-se-á sem quaisquer novos custos para a outra parte - aliás, esta ira aumentar seus rendimentos, já que não sofrerá queda de remuneração com a interrupção da execução do objeto contratual inicial).

$V I$ - Implicações do regime de contrato administrativo para a compreensão da ampliação do objeto inediato do segundo contrato de arrendamento peculiaridades do contrato en causa

Que os contratos de arrendamento portuário em análise consistem em contratos administrativos é constatação a essa altura incontendível, em apreço às razões supra expendidas $^{26}$. Caso, agora, de também identificar com mais precisão as conseqüências de tal natureza para o contrato em comento.

Dentre as características do regime jurídico dos contratos administrativos, assoma a alterabilidade de seu conteúdo. Mais: alterabilidade inclusive e notadamente unilateral, exercitável pela parte-Estado. Tal é o que releva da própria definição do instituto, segundo redação de Celso Antônio Bandeira de Mello, respaldada em extensa doutrina: "um tipo de avença travada entre a Administração e terceiros na qual, por força de lei, de cláusulas pactuadas ou do tipo de objeto, a permanência do vínculo e as condições preestabelecidas assujeitam-se a cambiáveis imposições de interesse público, ressalvados os interesses patrimoniais do contratante privado" 27 .

Nesse caminho, a alterabilidade dos contratos administrativos é função direta do interesse público que thes inspira a formalização e a execução. Esse interesse público, característico da relação jurídico-administrativa que é instaurada e vivenciada sempre sob "o influxo de uma finalidade cogente" 28 , traz por conseqüência um regime juridico de maleabilidade, plasticidade do conteúdo contratual: um regime público dinâmico, para usar expressão de Soto Kloss ${ }^{29}$.

Por outro lado, é certo e consabido que essa alterabilidade contratual, em nosso ordenamento jurídico, é restringida em face de duas razões:

i) proteção da situação jurídica do contratado, para que não haja (a) descaracterização do objeto contratual e eventual perda do interesse econômico na avença, ganha como direito subjetivo do particular; nem (b) exaurimento da posição econômica favorável defluída do contrato mediante solapamento da equação econômicofinanceira provocado por alterações contratuais.

20 Tópico II.3.

27 Curso de Direito Administrativo, São Paulo, Malheiros, $13^{a}$ edição, 2001, páginas 560 e 561 .

28 Ruy Cirne Lima, Princípios de Direito Administrativo, Porto Alegre, Globo, $3^{\mathbf{a}}$ edição, 1954, página 63.

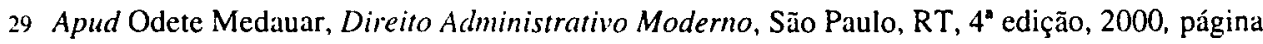
252. 
ii) evitar-se a burla ao procedimento licitatório, a qual, não fossem os limites de alteração contratual, restaria ensejada, uma vez formalizado o contrato, com a possibilidade do agente administrativo incrementá-lo, tornando-o consideravelmente mais vantajoso do que aquele originalmente licitado.

No regime jurídico comum dos contratos administrativos, tais limites encontram-se notadamente regidos pelo artigo 65 e seguintes da Lei $n^{\circ} 8.666 / 93$. Já vimos, entretanto, que sua aplicação, mesmo em se tratando de contratos administrativos comuns (considerados aqueles regidos integral e exclusivamente pelos artigos $54 \mathrm{e}$ seguintes da Lei $n^{\circ}$ 8.666/93) não se dá em todas as hipóteses de alteração contratual $^{30}$. No caso em análise, agregamos que o contrato de arrendamento de instalação portuária, se não duvidamos tratar-se de um contrato administrativo, também não pomos em dúvida que o mesmo não é regido integral e exclusivamente pelos artigos 54 e seguintes da Lei $n^{\circ} 8.666 / 93$. Sem que certamente deixe de submeter-se à referida lei, os contratos ora em consideração regem-se primeiramente (e dai decorrem algumas inovações em face do regime contratual administrativo ordinário) pela Lei $n^{\circ} 8.630 / 93$, que institui o regime jurídico dos Portos ${ }^{3 !}$.

Nisso, sublinhamos que, se a alterabilidade de conteúdo é um caractere íncito ao próprio conceito de contrato administrativo, vai ser, entre outras ${ }^{32}$, peculiaridade do regime jurídico específico dos contratos de arrendamento de instalação portuária uma maior intensidade dessa característica. Isto é: os contratos de arrendamento portuário demandam uma maior alterabilidade contratual. Em termos positivos, tal deflui da prescrição da Lei $n^{\circ} 8.630 / 93$, artigo $4^{\circ}$ :

"Artigo $4^{\circ}$. Fica assegurado ao interessado o direito de construir, reformar, ampliar, melhorar, arrendar e explorar a instalação portuária..."

E, mais adiante, o $\S 4^{\circ}$, VIII do mesmo artigo:

" $\$ 4^{\circ}$. São cláusulas essenciais no contrato a que se refere o inciso I do caput deste artigo, as relativas:

(...)

VIII - aos direitos, garantias e obrigações do contratante e do contratado, inclusive, quando for o caso, os relacionados com visíveis necessidades de futuras suplementações, alterações e expansões do serviço e conseqüente modernização, aperfeiçoamento e ampliação das instalações;"

A razão dessa maleabilidade de conteúdo contratual mais intensa, como não poderia deixar de ser, prende-se ao próprio fundamento da alterabilidade de conteúdo como caractere definidor do contrato administrativo - a necessidade de se adaptar, cambiar, mudar o teor das disposições contratuais para que se conformem às exi-

30 Ver Parágrafo 2. (i) e (ii), supra.

31 A existência em nosso ordenamento jurídico de regimes contratuais administrativos específicos ao lado do regime contratual administrativo ordinário é constatação palmar. Apenas como ilustraçĩo (sequer extensa, quanto menos exaustiva), lembramos os contratos de concessão e permissão de serviço público (com regência especial positivada pela Lei $n^{\circ} 8.987 / 95$ ), os contratos envolvendo concessão de potencial hidrelétrico (com regência especial positivada pela Lei $n^{\circ} 9.074 / 95$ ).

32 Como o prazo mais dilargado. 
gências cambiantes do interesse público. O que se entende, como em tantas coisas mais no Direito, conhecendo-se melhor a materialidade dos serviços portuários. Sem obviamente pretendermos nos arvorar em técnicos da engenharia operacional portuária, nem expertos em administração logística, impomo-nos as considerações fáticas seguintes como inescapável dever de ofício para a adequada compreensão jurídica do problema.

Os serviços portuários são efetivados sobre uma infra-estrutura que, embora gigante aos olhos leigos, em verdade pode sofrer de escassez - e a mera ociosidade de capacidade já é fato aqui negativo - dado o gigantismo das necessidades de embarque e desembarque de mercadorias e, sobretudo, ao regime especialmente acelerado em que tal serviço deve ser operado para que alcance seus préstimos: minoração das distâncias percorridas mediante (a) a máxima diminuição possível (em face dos meios de transporte conectados pelo Porto) de tempo para despacho aduaneiro da mercadoria $\mathrm{e}$ (b) diminuição dos custos vinculados à permanência da mercadoria no Porto.

Em face dessas exigências materiais, que consubstanciam o critério de eficiência desse serviço público, impõe-se ao concessionário do serviço de portos - no caso concreto, a concessionária - a permanente atenção logística voltada à otimização do emprego da infra-estrutura existente, quer (i) evitando-se o máximo possível sua ociosidade, quer (ii) incrementando-se o seu uso.

Nesse contexto, a própria estruturação do objeto contratual original dos contratos de arrendamento portuário deixa, $a b$ initio, inscrita como eventualidade prevista, a possibilidade de ampliação de seu objeto, donde a intensificação da nota de alterabilidade contratual, característica dos contratos administrativos. A alteração neste não é uma superveniência remota e improvável, não requer, pois, um fato especialmente inesperado.

Essa ampliação do objeto contratual se pode dar mediante (a) reforma das instalações ou (b) acréscimo de instalações à operação portuária avençada por dado contrato de arrendamento. Daí termos no início deste parecer usado a expressão objeto contratual imediato, querendo assim - sem que nisso vá qualquer veleidade de originalismo teórico, mas, tão-somente a necessidade de referir uma realidade que nos parece não fidedignamente traduzível pela terminologia comum dos contratos administrativos - aludir à existência, nos contratos de arrendamento de instalações portuárias, de um objeto contratual original (consubstanciado naquele inicialmente definido e certo e uma potencialidade desde já inscrita como evento previsto, embora incerto), o qual abrange um (1) objeto contratual imediato (aquele inicialmente definido e certo no Instrumento Contratual, in casu, aquele descrito no contrato) e um (ii) objeto contratual mediato ou potencial (o referente a uma potencialidade desde já inscrita como evento previsto, embora incerto). ${ }^{33}$

33 Insistimos que a sistematizaçĩo acima corresponde a um esforço de descrição de uma realidade jurídica que nos parece inequívoca. A discrição pode não ser a melhor e aqui certamente é feita em termos ensaísticos, o que não nos preocupa vez não confundirmos a natureza desta peça com um trabalho científico. Contudo que consegue a mesma chamar a atenção para peculiariedades do 
Mediante a ampliação prevista como evento normal e normatizado no artigo $4^{\circ}$, caput e $\$ 4^{\circ}$, VIII da Lei ${ }^{\circ} 8.830 / 93$ (ademais, contratualmente inscrita na avença), atualiza-se, definindo o que dantes incerto, o objeto contratual mediato (potencial) que passa a incorporar o objeto contratual imediato (presente e definido) do contrato de arrendamento. Nessa ampliação do objeto contratual imediato, na qual certamente se pode ver uma alteração contratual substancialmente indistinta daqueles ocorrentes com contratos administrativos em geral, queremos chamar a atenção para a peculiaridade intensificada de que a alteração contratual in casu corresponde a uma potencialidade consideravelmente expectada desde sempre para a avença.

A ampliação em referência, portanto, não pressupõe uma situação extraordinária, inusitada, emergencial, nem singularmente especial. A competência de ampliação do objeto contratual imediato da avença em causa, com expresso e especial lastro legal, é exercida discricionariamente, dependendo apenas da ocorrência fática que razoavelmente a justifique. Tal fato, entretanto, não é raro, nem incomum, mas gravita em torno da normalidade do modus operandi da economia portuária. Calham aqui as considerações da lavra da Consultoria Jurídica do Ministério dos Transportes, vazadas no Parecer CONJUR/N ${ }^{\circ}$ 039/2001, lançado nos autos do Processo $n^{\circ}$ 50000.005052/2001-30:

"Por outro lado, a Lei $n^{\circ} 8.630 / 93$ (...), dá respaldo legal à ampliação das instalações, em seu artigo $4^{\circ}, \S 4^{\circ}$, inciso VIII...

" (...)

"Vê-se que a norma supratranscrita dá certeza e segurança ao Administrador para autorizar a incorporação de área do Armazém 13 à área arrendada, posto que o referido Armazém, pelas peculiariedades operacionais do local em que se encontra encravado, caracteriza, de certa forma, a inviabilidade de ser utilizada por outros interessados...

“Desse modo está demonstrado nos autos a presença do interesse público, pois essa incorporação irá aumentar a movimentação de carga no Porto de Santos, uma das metas prioritárias da concessionária (...)"

Quanto aos limites da ampliação de objeto contratual imediato dos contratos de arrendamento em exame, não temos que se possa sem mais incidir os percentuais constritivos do artigo $65, \S \S 1^{\circ}$ e $2^{\circ}$. Estes são incindíveis quando não comparecer nenhum fundamento fático para a ampliação ou acréscimo de objeto contratual que, em face da engenharia logística peculiar do serviço portuário, justifique adição de área de instalação portuária em volume maior que $25 \%$ da área original (objeto contratual original imediato).

Há, todavia, eventualidades em que tal acréscimo de objeto além dos $25 \%$ (além, portanto, dos limites dos referidos dispositivos legais) constitui-se como necessidade reclamada para otimização do emprego de dadas áreas portuárias, quando, então. configura-se hipótese subsumível diretamente ao artigo 65 , I, a (ou, no mínimo, uma

contrato em comento e render-lhes didática indicação, isso não duvidamos. E por isso mesmo a empregamos. 
hipótese específica defluída da combinação desse dispositivo com o artigo $4^{\circ}$, VIII, da Lei ${ }^{\circ} 8.630 / 93$ ):

"Artigo 65. Os contratos regidos por esta Lei poderão ser alterados, com as devidas justificativas, nos seguintes casos:

"I — unilateralmente pela Administração:

"a) quando houver modificação do projeto ou das especificações, para melhor adequação técnica aos seus objetivos;"

E já se pode considerar pacificada a melhor doutrina quanto ao afastamento, em casos tais, do artigo $65, \S \S 1^{\circ}$ e $2^{\circ}$ da Lei $n^{\circ} 8.666 / 93$ como limites ao aditamento ou ampliação do objeto contratual que se demonstre necessário fazer. Por todos, Celso Antônio Bandeira de Mello acerca desses referidos dispositivos legais constritivos magistra:

"Parece-nos, entretanto, que a dicção legal, conquanto muitíssimo salutar, não deve ser recebida de modo extremado. É que, por mútuo acordo, segundo entendemos, poderia caber modificação excedente dos limites previstos no $\S 1^{\circ}$ do artigo 65 caso ocorra alguma situação anômala, excepcionalíssima, que a justifique, ou, então, em face das chamadas 'sujeições imprevistas'; isto é: quando dificuldades naturais insuspeitadas se antepõem à realização da obra ou do serviço, exigindo tal acréscimo. Seria o caso, 'exempli gratia', de o perfil geológico revelar-se diferente daquele constante dos dados oferecidos pela Administração ou descoberta de um lençol freático insuspeitado." 34

Esclarecemos que Bandeira de Mello, ao referir o requisito de excepcionalidade da situação, certamente considera o costumeiro dos contratos administrativos, como não poderia deixar de ser em capítulo de curso jurídico em que se expõe sobre a generalidade desses negócios. No caso concreto, entretanto, a ampliação da área arrendada, mesmo em patamares superiores a $25 \%$ da área original (objeto contratual imediato), se não pode ser tomada como fato futuro e certo no instante da formalização da avença, claramente apresenta-se, tanto em face das idiossincrasias materiais da infra-estrutura e do serviço público em referência quanto por regência legal específica (Lei $n^{\circ} 8.630 / 93$, artigo $4^{\circ}, \S 4^{\circ}$, VIII), um caractere de eventualidade expectada, não se caracterizando assim necessariamente pela excepcionalidade referida pelo festejado Titular da PUC/SP.

De qualquer modo, atalhando polêmicas, no caso concreto os fatos subjacentes à decisão de ampliar o escopo contratual imediato do contrato de arrendamento claramente pode ser entendido como excepcional, visto não ser do costumeiro das vicissitudes contratuais dessas avenças que sua continuidade seja inviabilizada pela perda do objeto contratual em face da construção de via portuária. Há, pois, aqui, uma situação fática excepcionalíssima.

Seja notado ainda que a subsunção legal, nessas hipóteses, não é possível sem o intercurso de um juízo técnico-administrativo, o qual - sem embargo de sindicável perante pautas de consistência técnica, razoabilidade e proporcionalidade jurídicas — enseja não raro apreciação discricionária do agente administrativo competente.

34 Curso de Direito Administrativo. São Paulo, Malheiros, 13a edição, 2001, página 568. 
Essa observância impõe-nos um limite: só podemos concluir pela presença ou não de condições fáticas e fundamento jurídico para que o agente administrativo competente decida, exercendo a discrição administrativa que lhe cabe, em favor ou não da ampliação do contrato. Caso não estivessem presentes tais pressupostos (fatos e fundamento jurídico), responderíamos em termos peremptórios contrariamente à licitude da ampliação contratual cogitada. Como, todavia, já avisamos desde o início que antevemos o comparecimento de aludidos requisitos, nossa resposta - assim como o controle administrativo ou jurisdicional externos - deve ir somente até à assertiva de que pode o agente administrativo assim decidir. Nesse caso, a ele e somente a ele, agente administrativo, a decisão.

Com esses avisos, podemos concluir esse tópico. opinando favoravelmente à licitude da ampliação contratual cogitada, porquanto, presentes justificações técnicas concernentes à necessidade de se otimizar o emprego de área portuária, rendendo ganhos de eficácia e produtividade ao serviço prestado. Em reforço, são as considerações pertinentes lançadas pela Procuradoria da Fazenda Nacional, por sua Coordenação Geral-Jurídica:

“(...) menciona-se que, .... a ... realizou Audiência Pública sobre a licitação para a recuperação e modernização da Avenida Perimetral Portuárias, acessos e saídas, e infra-estrutura para a automação das operações do Porto de Santos.

Como essas obras serão realizadas, em áreas do porto organizado, haverá mudanças nos traçados das atuais rodovias e ferrovias internas, com a utilização de novas áreas e com o não-uso das vias que serão extintas.

É claro que, com essas alterações, serão atingidos pátios de manobra, de estacionamento e de movimentação de cargas, armazéns, edificações administrativas, silos etc.

"Qualquer permuta ou acréscimo de áreas conseqüientes a essas alterações são perfeitamente legais, ensejando alterações dos respectivos contratos, sem nova licitação."

VII - A ampliação do contrato como legítimo ato administrativo ressarcitório da "empresa" contratada e neutralizador de claro e fundado direito indenizatório - ganhos para o interesse público, referidos ao serviço público em causa e ao patrimônio público tutelado pela concessionária

Sendo os contratos de arrendamento entretidos pela empresa junto à concessionária em causa contratos administrativos (aliás, fossem singelos contratos comuns, tanto mais se punha a conclusão adiante), é próprio de sua normatividade a instituição de direitos e deveres jurídicos para ambas as partes. Consoante o sabido por qualquer graduando que tenha feito sua primeira leitura de qualquer curso de direito administrativo, capítulo dos Contratos Administrativos, o aperfeiçoamento de uma avença dessa estirpe institui juridicamente um sinalagma entre as partes contratantes, constituindo-se a partir daí um plexo de direitos e deveres contrapostos. O sentido econômico subjacente a esse arranjo de direitos e deveres é sinteticamente referido 
como equação econômico-financeira e sua proteção - negritemos: intensa proteção - consiste desses casos raros em que doutrina, nacional e estrangeira, e ainda a jurisprudência, comungam em uníssona opinião. ${ }^{35}$

Firmado o contrato, vindo seu objeto, em meio a vigência e execução contratuais, a ter sua exploração economicamente inviabilizada, a extinção contratual daí ocasionada, porque de responsabilidade da concessionária (a causa material da inviabilização consiste na construção de uma via portuária por iniciativa desta), configura hipótese de quebra da equação econômico-financeira da avença e assim institui em favor da empresa o concernente direito à proporcional compensação.

Tal se entende porquanto referida equação econômico-financeira, presente em todo e qualquer contrato de conteúdo econômico apreciável (a especialidade do contrato administrativo, nesse tema. diz apenas com a intensidade da proteção da equação), abrange um planejamento de custos e investimentos (encargos financeiros) aos quais correlacionado um programa de ganhos que, considerados ao longo da vigência contratual pactuada, proporcionarão a remuneração do capital investido (lucro). Diante desse programa econômico da contratação, a diminuição abrupta de sua duração implica em direta queda de volume de ganhos e, por conseqüência incontornável, perda de remuneração de capital investido. Trata-se, pois, de hipótese fática inegavelmente eficaz em produzir abalo à equação econômico-financeira.

Uma vez formalizado o contrato, contratada entre as partes a equação econômico-financeira a ele subjacente, a proteção institucional da mesma obriga, in casu, à concessionária a respeitá-la, do que decorrem em caso de quebra da equação em referência:

(i) ou o direito à recomposição da equação econômico-financeira da avença, ou

(ii) se empecida a persistência do contrato em causa em face da inviabilização econômica da exploração da parcela de sua área persistente após a construção da via portuária, o direito à indenização integral dos custos havidos e das justas expectativas de lucro compromissadas mediante referido negócio. ${ }^{36}$

35 Ajuntaríamos como referência, as contribuiçōes de: Rivero, Jean, Droit Administratif, $3^{\mathrm{a}}$ edição, Dalloz, 1965, página 108; Benoît, Francis-Paul, Le Droit Administratif Français, Dalloz.1968, página 588; Peguinot, Georges, Theórie Génerale du Contract Administratif, Paris, A. Pedone, 1945, páginas 433 e 434: Waline, Marcel, Droit Administratif, $9^{a}$ edição, Sirey, 1963, página 618: Caetano, Marcello, Princípios Fundamentais de Direito Administrativo, Forense, 1977, páginas 255 e 256; Laubadére, André de, Traite Theórique des Contrats Adminsitratifs, Tome I, Paris, paginas 85 a 103; Mattos de Vasconcelos (RDA II/153), o Ministro Oscar Saraiva (RDA 1/323: V/277; X/284; XXV/257), Guimarães Menegale (RDA XXVII/312), Alcino Salazar (RDA XXXI/301), Alfredo de Almeida Paiva (Aspectos dos Contratos de Empreitada, Rio, Forense, 1955, página 68) e Clóvis Paulo da Rocha (Revista Jurídica da Faculdade Nacional de Direito, XVII/143, 1959). Em remate, vale colacionar também as seguintes obras, mais recentes até: Carlos Henrique Magalhães Marques (RDP 91/103); Eros Roberto Grau (RDP 96/61); e Hely Lopes Meirelles (Estudos e Pareceres de Direito Público, volume 11/80 e volume III/02).

36 Celso Antônio Bandeira de Mello, em texto de agudeza impar, expõe a ratio jurídica em causa (Curso de Direito Administrativo, São Paulo, Malheiros, $12^{\star}$ edição, 2000, páginas 560 e 561):

“... a indole deste tipo de relações entre a Administração e particular assenta no respeito mútuo de interesses. Pretende-se encarecer que se trata de vínculo - segundo doutrina dominante na 
A consideração isolada e exclusiva dessa contingência já por si - insistimos: só e exclusivamente por si - enseja fundamento legítimo bastante para a ampliação do objeto contratual imediato do ajuste, considerando-se tal ampliação como lídimo ressarcimento à empresa pela quebra da equação econômico-financeira do contrato (fato lesivo), provocadora de perda de justas expectativas de lucro (consubstanciação de dano indenizável), por conseqüência de fato de exclusiva responsabilidade da concessionária (caracterização e personificação da responsabilidade ressarcitória).

E a licitude da medida tanto mais é reforçada quando observado que se ajuntam em prol de sua concretização duas considerações em torno do Princípio Jurídico da Finalidade (entendido, aqui em seara jusadministrativa, como impositivo da atuação administrativa que melhor atenda ao interesse público) focadas perante o caso concreto. Além de corresponder a lídimo ressarcimento de dano indenizável em favor da empresa, a ampliação do escopo contratual imediato do contrato de arrendamento se legítima como medida lícita e aconselhável porque:

A uma, otimiza a operação portuária nas áreas que abrange. proporcionando ganhos de produtividade e de eficiência na prestação do serviço público administrado pela concessionária, no que se revela a consecução de aspecto relevante do interesse público imbricado no caso concreto;

A duas, evita despesa para o patrimônio público gerido pela concessionária. à medida que, não somente neutraliza revés econômico que, de outro modo, ser-lhe-ia imposto face ao direito de ressarcimento titulado pela empresa, cono também proporciona a manutenção do incremento patrimonial público correspondente. em razoável medida, à remuneração que, cabível em favor da concessionária, restaria prejudicada pela inviabilização econômica de sua continuidade.

atualidade - no qual o chamado contratante privado é havido como um colaborador da Administração, de tal sorte que: 'tende a prevalecer a idéia de que o interesse do Estado é de assegurar uma remuneração normal (e nāo mais o menor lucro possível) a seu contratante. que vai ser associado, não como um executante sem iniciativa, mas como um colaborador ao qual tais iniciativas. pelo contrário, são pedidas em favor de uma tarcfa de interesse público".

“...cai a lanço observar que a posição jurídica da Administração, em suas múltiplas relaçōes publicas. difere substancialmente da posição dos particulares quanto aos objetivos que podem animá-los. Ao contrário destes últimos, o Poder Público não tem móvel de lucro, de ganho, de especulação. Seu móvel é apenas e tão-somente a utilidade puiblica.

"(...)

"Enquanto o particular procura o lucro, o Poder Público busca a satisfação de uma utilidade coletiva. Calha, pois, à Administração atuar cm seus contratos com absoluta lisura e integral respeito aos interesses econônicos legítimos de scu contratante, pois não lhe assiste minimizá-los em ordem a colher benefícios cconômicos suplementares ao previsto e hauridos em detrimento da outra parte.

"Para tanto, o que importa, obviamente, nāo é a 'aparência' de um respeito ao valor contido na equação econômico-financeira, mas o real acatamento dele. De nada vale homenagear a forma quando se agrava o conteúdo. O que as partes colimam em un ajuste não é a satisfação de fórmulas ou fantasias, mas um resultado real, uma realidade efetiva que se determina pelo espirito da avença; vale dizer, pelo conteído verdadeiro do convencionado." 
Sobre ser lícita, portanto, a solução cogitada pela concessionária para recomposição dos interesses e direitos tocados pela inviabilização econômica da continuidade do contrato é aconselhável. Como arremate tópico, oportuna a cita do seguinte aresto do Supremo Tribunal Federal, que, ao ensejo de hipótese fática muito aproximada, avalizou solução tomada pela Prefeitura Municipal do Distrito Federal (ao tempo do Rio de Janeiro capital), de inspiração similar àquela subjacente à medida cogitada e aqui comentada:

"EMENTA: Não é ilegal o ato do Prefeito que acertou com o concessionário da exploração de um parque de diversões a prorrogação por mais de três anos, a troco da vantagem de mudança do local, sem despesas para a Prefeitura." ${ }^{37}$

No corpo do voto do Ministro Mário Guimarães, flagra-se o tirocínio jurídico irretorquível:

"A explicaçāo da Prefeitura foi cabal: funcionava na Quinta da Bôa Vista, há mais de cinco anos, um parque de diversões. A Prefeitura precisou do local para instalação do Jardim Zoológico, transferido para aquela Quinta. Entrou em entendimento com o proprietário do Parque, que se mudou para outro local, na mesma Quinta. Como, porém, essa transferência acarretaria despesas para o concessionário, do acordo constou que ele teria, como indenização dessas despesas, prorrogada por mais três anos a autorização."

"Desse ato não resultou qualquer violação de direito do impetrante, desejoso de inscrever-se numa hipotética concorrência pública."

VIII - Compatibilidade entre a ampliação contratual cogitada e o princípio da isonomia

Cabe, enfim, ainda uma última indagação. Sem embargo dos vários aspectos jurídicos positivos supra flagrados em prol da medida cogitada pela concessionária, não seria a mesma atentatória ao Princípio da Isonomia por eventualmente ensejar o arrendamento de áreas portuárias sem prévia e específica licitação e assim proporcionar tratamento jurídico diferenciado à empresa contratante?

Temos que não.

Ensina Antonio Roque Citadini que "a igualdade não é uma regra de equiparação matemática, mas sim um princípio relativo a cada caso em concreto. Isso equiivale a dizer que o tratamento isonômico só é aplicável entre aqueles que encontram na mesma situação ou condição jurídica, devendo os díspares ser tratados conforme suas peculiares condiçōes." 38

Daí, antes de imaginarmos que todas as formas de discriminação ferem a garantia de isonomia. devemos saber reconhecer em que casos essa discriminação é ou não

37 STF, RMS 1835/DF, Pleno. Relator Ministro Mário Guimarães, DJ 24.09.53, in http://www.stf.gov.br.

38 Comentários e Jurisprudência sobre a Lei de Licitações Públicas, $2^{a}$ edição, São Paulo, Max Limonad, 1997, página 39. 
legítima. É o que esclarecem Lúcia Valle Figueira e Sérgio Ferraz, ao afirmarem que "fundamental para saber qual é o conteúdo jurídico do princípio da igualdade é, por incrivel que pareça, conhecer quando é válida a desigualdade. Se soubermos quando podemos discriminar. conheceremos o conteúdo jurídico do principio da igualdade. Isso significa que é preciso que se investigue, com profundidade, qual o traço de legitimidade que fundamenta, perante o ordenamento jurídico, determinado fator discricionário. Isso determinará a observância ou inobservância do preceito da igualdade." 39

Por óbvio, não cabe aqui repertoriar exaustivamente as hipóteses fáticas que justificariam um tratamento jurídico similar àquele cogitado pela concessionária. Mais profícuo e objetivo é identificar no caso concreto o que pode ser considerado como idiossincrasias fáticas hábeis, por sua eficácia em singularizar o caso concreto, a dar fundamento ao tratamento específico.

Ora, avulta, in casu, a condição da empresa, (i) arrendatária da concessionária no contrato, de (ii) potencial credor desta em face de (iii) abalo de equação econômico-financeira subjacente ao (iv) contrato entretido entre ambas, (v) cuja continuidade restará impedida por inviabilização da exploração econômica de seu objeto, provocada por (vi) fato de exclusiva responsabilidade da concessionária. Seis aspectos fáticos, portanto, diretamente correlacionados à situação fático-jurídica da empresa e que a peculiarizam já por permitirem configurar fato jurídico inegavelmente específico: a caracterização da solução contratual aventada pela concessionária como medida ressarcitória da empresa.

A essa situação jurídica peculiar em que inserida a empresa, agregam-se todas as considerações outras supra explanadas, as quais, mais atinentes ao regime da atividade e do contrato em causa (e não exatamente à pessoa da empresa), também peculiarizam fática e juridicamente a hipótese relatada por esta, indicando a justeza de uma solução desigualada do ordinário à medida em que a situação não é ordinária.

Em face desse contexto, suposta afronta à igualdade somente dar-se-ia caso, presente outro sujeito em situação símile à interessada (i.é., que também se qualificasse pelo seis aspectos fáticos identificados no parágrafo penúltimo supra), não se lhe estendesse tratamento idêntico ao que cogitado pela concessionária sem apresentar-se justificativa objetiva e razoável para a solução eventualmente desequiparada.

Isso não comparecendo, a solução contratual aventada pela concessionária e ora analisada sobressai conformada com o cânone da isonomia.

\section{$I X-$ Conclusão}

Feitas essas ponderações, é com confortável e tranqüilo estofo nas mesmas que respondemos favoravelmente à licitude da ampliação do objeto contratual imediato 
do contrato, retomando aqui a conclusão dantes antecipada e concernentes fundamentos, partidos da consideração de que:

i) A atividade desenvolvida ao ensejo de referido contrato é de serviço público, o que submete a relação contratual a um regime juspublicista em que vigente o Princípio da Continuidade do Serviço Público; de seu lado, este impõe aos agentes públicos incumbidos da prestação do serviço velar com todos os meios possíveis pela continuidade da prestação do serviço, continuidade esta que não se cinge à mera permanência de uma operação material, mas, sim, a permanência ótima da operação material em que se consubstancia o serviço: sob essa diretriz, a ampliação do objeto contratual imediato da referida avença homenageia a persistência da operação dantes desenvolvida na área abrangida pelo contrato e a otimização da funcionalidade do espaço das instalações portuárias adjacentes à área abrangida inicialmente pelo instrumento.

ii) O contrato em tela é um contrato administrativo, e, por decorrência do regime geral dos contratos administrativos, caracteriza-se pela alterabilidade como regra imanente; demais, por peculiaridade jurídica defluída da Lei $\mathrm{n}^{\circ} 8.630 / 93$, tal alterabilidade é característica intensificada nos contratos de arrendamento de instalações portuárias ensejando a ampliação do objeto contratual original imediato quando (sob apreciação discricionária do agente administrativo competente) as condições estruturais da área adjacente àquela objeto do contrato podem ser otimizadas - e assim potencializada a efíciência do serviço público em causa --, estendendo-se-lhe a operação da avença em tela.

iii) Tal opção administrativa (discricionária) tanto mais se revela legítima quando notada que a mesma neutraliza, por compensação material, claras e fundadas pretensões ressarcitórias da empresa, as quais adviriam em desfavor da concessionária (e assim do patrimônio público que a mesma tutela) com a rescisão do contrato por fato atribuível à responsabilidade desta última.

iv) Ainda corrobora tal conclusão, a observância de que a medida, a par de neutralizar revés financeiro em desfavor do patrimônio público tutelado pelo Estado, oportuniza-lhe ganhos, seja (a) de produtividade com a otimização de sua operação portuária nas áreas abrangidas pela cogitada ampliação, seja (b) pela permanência da remuneração correspondente (ainda que, por eventualidade, de forma não integral) ao que cabia à concessionária ao ensejo da execução do contrato em comento.

v) Demais não comparece afronta à isonomia no caso em análise. Ao contrário, a medida cogitada consubstancia tratamento isonômico no passo em que especialmente desenvolvida para situação que se apresenta razoável e proporcionalmente específica. Em suma: trata-se de um tratamento não ordinário para uma situação que não é ordinária. 


\section{A Intervenção do Estado no Domínio Econômico}

\section{Alberto Venâncio Filho}

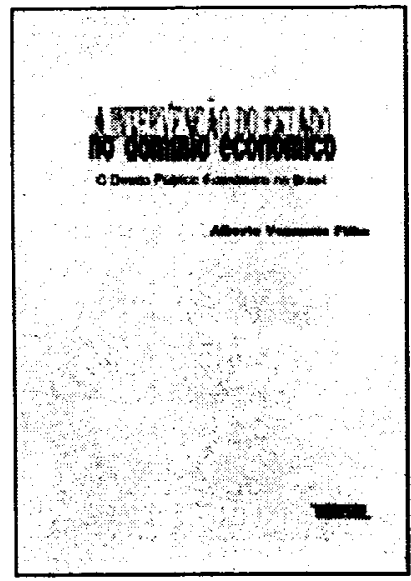

É estudada aqui a atividade do Estado no Domínio Econômico, os princípios constitucionais, e os mais diferentes aspectos do "Direito Regulamentar Econômico" na agricultura, indústrias extrativas, setor energético, financeiro e comércio exterior, etc. É um estudo exaustivo. A época mudou. A década de 60 se caracterizava pela política de substituiçāo de importações, o estado como motor do desenvolvimento. Hoje, rivemos a internacionalização da economia realizada, acima de tudo, pelas empresas norte-americanas. É o neoliberalismo.

Ref. 0171

Form. 16x23

Encadernado 614 págs. 1998

\section{A Lei das S.A.}

Alfredo Lamy Filho

José Luiz Bulhões Pedreira

Escrito pelos elaboradores do Anteprojeto que resultou na rigente Lei 6.404, de 1976, o livro reúne os pressupostos doutrinários e os debates ocorridos durante a elaboração e discussão do Anteprojeto ( $1^{\circ}$ volume).

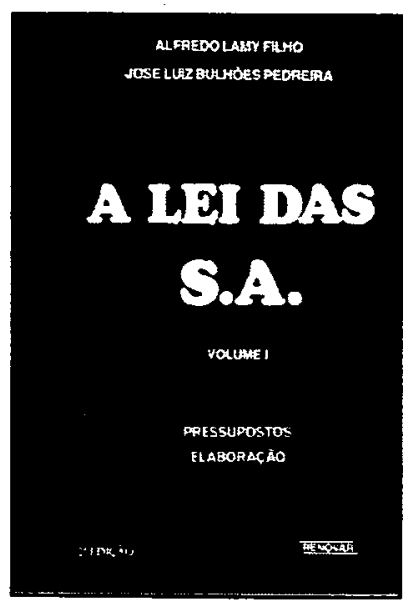

$1^{\text {o }}$ volume 428 págs.
Ref. 0044

Form. 16x23
Encadernado $1997-3^{\mathbf{a}}$ ed. 